\title{
Darwin and the Problem of Natural Nonbelief
}

\begin{abstract}
Problem one: why, if God designed the human mind, did it take so long for humans to develop theistic concepts and beliefs? Problem two: why would God use evolution to design the living world when the discovery of evolution would predictably contribute to so much nonbelief in God? Darwin was aware of such questions but failed to see their evidential significance for theism. This paper explores this significance. Problem one introduces something I call natural nonbelief, which is significant because it parallels and corroborates well-known worries about natural evil. Problems one and two, especially when combined, support naturalism over theism, intensify the problem of divine hiddenness, challenge Alvin Plantinga's views about the naturalness of theism, and advance the discussion about whether the conflict between science and religion is genuine or superficial.
\end{abstract}

\section{Introduction}

Perhaps the best-known evolutionary challenge to theism stems from biological evil (Draper 2007a; Kitcher 2007; Murray and Ross 2006; Smith 1991). Natural selection is a highly cruel process, and as Darwin noted long ago, a "devil's chaplain might write on the clumsy, wasteful, blundering, low and horribly cruel works of nature" (1856). But Darwin wasn't just concerned about evil. He also worried about nonbelief. In particular, Darwin seems to have realized that

(1) Evolution gave rise to early humans who lacked a concept of God, the result of which has been much nonbelief in God.

As Darwin appreciates, the human mind was not originally biased toward theistic belief since, as he puts it, "the idea of a universal and beneficent Creator does not seem to arise in the mind of man, until he has been ele-

"Darwin and the Problem of Natural Nonbelief" by Jason Marsh,

The Monist, vol. 96, no. 3, pp. 349-376. Copyright (C) 2013, THE MONIST, Peru, Illinois 61354. 
vated by long-continued culture" $(2004,682)$. In addition, Darwin's own struggles with belief in God (or at least the struggles of many since him) ${ }^{1}$ reveal that

(2) An acquaintance with evolution directly leads many to sense that the universe is indifferent to them, which often weakens or destroys their belief in God.

(3) An acquaintance with evolution generates certain atheological arguments and further tends to undermine biological design arguments, which for some weakens or destroys their belief in God.

Claim (1) concerns the process of evolution and its impact on the beliefs of early humans. Claim (1) also introduces what I call the problem of natural nonbelief. Claims (2) and (3) concern, not the process of evolution or its impact on the religious beliefs of early humans, but how our discovery and awareness of evolution impacts the religiosity of present human beings. My task will be to show that these three claims, especially when combined, have widespread significance for philosophy of religion. In particular, they support naturalism over theism, corroborate the evolutionary problem of evil, according to which the cruel workings of natural selection provide evidence that evolution is blind as opposed to guided, and challenge a widely endorsed view within religious epistemology about the naturalness of belief in God. In addition, these claims make a solution to the problem of divine hiddenness more difficult to come by and further reveal that the conflict between evolution and theism is, despite what many respectable thinkers have claimed in recent years (Sober 2011; ${ }^{2}$ Plantinga 2011; Van Inwagen 2003; Haught 2000; Miller 1999) not entirely superficial.

I will proceed as follows. Section One recalls the problem of natural evil in the distant past and explains how our knowledge of evolution intensifies this problem. This will set the reader up for Sections Two and Three, which explore the interestingly analogous problem of natural nonbelief in the distant past and how our knowledge of evolution intensifies this problem. Here some implications for Alvin Plantinga's remarks about the naturalness of belief in God are also drawn. Sections Four and Five turn to the present time and explore how evolution gives rise to nonbelief after Darwin. These sections further explore neglected Darwinian and cognitive dimensions to the argument from divine hiddenness, dimensions 
which strengthen that argument. Finally, to clarify my aims in this paper (unlike some popular figures in the conversation about science and religion) I am not attempting to disprove theism here - theism could still be true, for all I say, and could find better support than naturalism in other data, like cosmic fine-tuning. ${ }^{3} \mathrm{I}$ am also not attempting to devalue theism. My goal is merely to explore some overlooked challenges for theism, challenges that can impact our view of how it fares on our public evidence, including our scientific evidence.

\section{Terminology}

Since my main focus in this paper is with theism and naturalism, ${ }^{4} \mathrm{I}$ will have little to say about nontheistic religion or about secular alternatives to naturalism. By 'theism' I mean the claim that an unsurpassably powerful, intelligent, and loving God exists and has designed the world. ${ }^{5}$ By 'naturalism' I mean the claim that no supernatural agents exist, that the world was not intentionally designed, and that nature is causally closed and morally indifferent to human beings and to their flourishing. ${ }^{6} \mathrm{By}$ 'evolution' I mean the claim that all biologically complex life forms are related and are gradually modified descendants from less complex single-celled organisms. By 'Darwinism' I have in mind the claim that natural selection, working on random mutation, is the driving force behind much, if not most, evolutionary change. By 'natural selection' I mean, very roughly, the process by which traits are selected in a population because of their survival and reproductive value. I realize that some will reject Darwinism, or even evolution, though I should clarify that this paper is primarily intended for those who accept Darwinian evolution. ${ }^{7}$ It is also intended, as shall become clearer later on, for those who are open to scientific, including cognitive, accounts of religion.

\subsection{The problem of natural evil}

With these definitions and qualifications in mind, let us now consider Draper's claims about evolution and evil, which will, in turn, help to set up our largely parallel discussion about evolution and nonbelief. Draper begins with the age-old problem of natural evil. He states his evidence as follows:

E: For a variety of biological and ecological reasons organisms compete for survival, with some having an advantage in the struggle for survival over others; as a result, many organisms, including many sentient beings, never 
flourish because they die before maturity, many others barely survive but languish for most or all of their lives, and those that reach maturity and flourish for much of their lives usually languish in old age; in the case of human beings and some nonhuman animals as well, languishing often involves intense or prolonged suffering. (2007a)

Draper rightly notes that there are many losers in the competition for survival. We can get a more vivid sense of the kind of competition and suffering in question, however. Quentin Smith, for instance, presents us with the following example that we are supposed to feel in our bones:

Not long ago I was sleeping in a cabin in the woods and was awoken in the middle of the night by the sounds of a struggle between two animals. Cries of terror and extreme agony rent the night, intermingled with the sounds of jaws snapping bones and flesh being torn from limbs. One animal was being savagely attacked, killed and then devoured by another. A clearer case of a horrible event in nature, a natural evil, has never been presented to me. It seemed to me self-evident that the natural law that animals must savagely kill and devour each other in order to survive was an evil natural law and that the obtaining of this law was sufficient evidence that God did not exist. $(1991,159)$

With these things in mind, Draper argues as follows:

(P1) We know E to be true.

(P2) Naturalism has much more predictive power with respect to $\mathrm{E}$ than theism.

(P3) Naturalism starts out at least as plausible as theism (i.e., naturalism is at least as probable as theism independent of all evidence).

(C) So, other evidence held equal, theism is very probably false.

As for the argument, P1 is difficult to deny. That is, the kind of suffering described in $\mathrm{E}$ is clearly observable for all to see, even for those who doubt the truth of Darwinism. As for P2, this too seems plausible. We have more reason to expect $\mathrm{E}$ on naturalism than on theism. This is because, as Draper notes, an unsurpassably loving and powerful God couldn't care more about the earthly flourishing of sentient creatures and couldn't be more capable of securing it. If naturalism is true, by contrast, the universe can be expected to be quite indifferent to our suffering, including the suffering reported by E. True, God might have reasons that 
we can't imagine for permitting E, as so-called skeptical theists will point out. ${ }^{8}$ But it is no less likely that God has reasons that we can't imagine for never permitting E, which leads Draper to focus on the moral reasons we are aware of in connection to E. Since the issue is over what reasons we are aware of, and since we are aware of good reasons for E on naturalism, P2 seems plausible.

Turning to P3, Draper actually thinks that naturalism starts out much more plausible than theism. ${ }^{9}$ But I prefer my weaker premise that naturalism starts out at least as plausible as theism. To avoid disputes about intrinsic probability, however, we could put the argument in the form of a likelihood inequality:

$$
\operatorname{Pr}(\mathrm{E} \mid \text { naturalism })>\operatorname{Pr}(\mathrm{E} \mid \text { theism })
$$

Now the basic argument here could have been formulated before Darwin. We have long known about natural evil. But the second stage of Draper's argument is to suggest that our acquaintance with evolution intensifies the problem.

\subsection{What Darwinism contributes to the problem of natural evil}

The reason that Darwinism makes E even more problematic for theism is that $\mathrm{E}$ is to be expected on Darwinism, and because Darwinism is itself more to be expected on naturalism than on theism. In Draper's words,

Given naturalism, we are justly confident in the truth of Darwinism, not because we know in any historical detail exactly how natural selection led to biological complexity, but rather because natural selection provides a way of explaining such complexity without having to appeal to the purposes of a supernatural designer. If theism is true, however, then natural selection is not needed to solve the problem of apparent teleological order in the living world. Theistic evolution could be Darwinian, but it could also proceed in a variety of other non-Darwinian ways. As long as a perfect God is guiding evolutionary change, natural selection is not crucial for the development of biological complexity. Thus, given theism, it would not be surprising at all if natural selection played no significant role in the development of such complexity. This means that, if $\mathrm{E}$ is to be expected on Darwinism, then that is a predictive success for naturalism, but not for theism.

Put in a slightly different way, if naturalism is true, and if there is to be biological life, ${ }^{10}$ we have reason to expect that evolution will be heavily guided by cruel 'survival selection', to borrow a phrase from Draper, and 
thus reason to expect something like E. For when it comes to producing complex structures and establishing them in a population, evolution by natural selection appears to be essential, given naturalism. On the other hand, if theism is true, and if there is to be biological life, the situation looks different. God, being omnipotent, has various creative options. God could perhaps use various non-Darwinian forms of evolution to create. But God could equally use some form of special creation, or some combination of special creation and evolution to create. This creative flexibility would give God a way around E. In light of these claims, then, given the truth of Darwinism, the ratio of the predictive power of naturalism to the predictive power of theism has increased.

\subsection{Suffering in the past}

A final point about the argument from evil is worth considering before moving on to discuss nonbelief. Once we appreciate that much of the suffering reported by $\mathrm{E}$ has been going on for millions of generations, this only seems to further strengthen the case for P2, which says that naturalism has more predictive power with respect to $\mathrm{E}$ than theism. The reason for this is not that we now have even more evidence for suffering. We already have plenty of such evidence. The reason is rather that the reality of animal suffering over millions of generations deflects certain objections that might otherwise be raised against P2. For instance, many theists, in an attempt to preserve the natural goodness of God's creation, have been tempted to attribute the world's seemingly natural evil and suffering to a human fall. But this move becomes highly implausible if natural evil predates humans by millions of years.

In light of these claims, some theistic philosophers have sought out other ways around the problem of animal suffering in the distant past. I have my doubts about these attempts. ${ }^{11}$ Instead of pursuing them here, however, let us now turn to our discussion about evolution and nonbelief (and specifically evolution and nonbelief in a theistic or theistic-like God). ${ }^{12}$

\section{The Problem of Natural Nonbelief}

A common claim made by theists is that human beings have been made for a divine-human relationship, not just in the hereafter, but in the present. Indeed, it is widely thought, especially in the Abrahamic traditions, that such a relationship is of serious value, the main goal of creation, and something that urgently needs to be entered into by everyone. Some 
go further, claiming that the very concept of unsurpassable love, whatever Abrahamic theists have said, rules out the prospect that some would, through no fault of their own, fail to enjoy a relationship with God during their natural lives (Schellenberg 2007, 202). Claims like these have led many believers to be puzzled by the so-called hiddenness of God, which permits apparent cases of blameless nonbelief in a theistic God and which prevents some from entering into a divine-human relationship in this life. In fact, many philosophers see the puzzle in question as clear evidence for atheism, since a perfectly loving God wouldn't, goes the worry, tolerate anyone's failing to enjoy a divine-human relationship on account of his or her poor epistemic situation.

Some theists, hoping to resist the atheological import of divine hiddenness, attempt to deny the existence of blameless or nonresistant nonbelief, ${ }^{13}$ where 'nonresistant nonbelief' means, roughly, that the nonbelievers in question are not resisting the divine and would believe in a theistic God given sufficient opportunity. Such denials are already controversial enough, even among theists. But they should become more controversial in light of a phenomenon I will call 'natural nonbelief', which may be the most significant species of nonbelief. By 'natural' in this context, I mean what philosophers mean when they call certain forms of evil natural, viz., natural in the sense of being built into the physical or biological structure of the world, and being generally outside the scope of human agency and control. I do not mean to imply that nonbelief is 'cognitively natural', though I will soon suggest that belief in a theistic God is less 'cognitively natural' than we might expect if theism were true. Thus the problem of natural nonbelief is the problem that much of the world's nonbelief, if theism is true, will be a consequence of the manner in which God decides to create the world and the human mind, and will not be plausibly attributed to human agency, free will, or moral shortcomings.

\subsection{Nonbelief in the past}

So why should we think that natural nonbelief in God really exists? Here it is helpful to look to the past. As Darwin notes, there was a time in human history without theism, a time where the religious landscape was restricted to cruel and limited spirits:

I am aware that the assumed instinctive belief in God has been used by many persons as an argument for His existence. But this is a rash argument, as we should thus be compelled to believe in the existence of many cruel and 
malignant spirits, only a little more powerful than man; for the belief in them is far more general than in a beneficent Deity. The idea of a universal and beneficent Creator does not seem to arise in the mind of man, until he has been elevated by long-continued culture. $(2004,682)$

Darwin's aim in this passage is not to challenge the truth of theism ${ }^{14}$ but to challenge the idea that the cognitive naturalness of theism is evidence for the truth of theism. In any case, Darwin's words remind us of something that both advocates and critics of the hiddenness argument tend to overlook, namely that a concept of a High God appears to be a relative latecomer in the cultural history of religion.

Darwin's claims are corroborated by recent work in the cognitive science of religion (hereafter CSR). Consider the following words from Justin Barrett, for instance: "Arguably the oldest and most widespread form of god concepts is the ancestor spirit or ghost, a type of afterlife belief' $(2007,775) .{ }^{15}$ Elsewhere Barrett notes that, even in the present, the human mind is naturally disposed to believe in various forms of supernatural agency and not just theism. He states,

Commonly scholars in the cognitive science of religion (CSR) have advanced the naturalness of religion thesis. That is, ordinary cognitive resources [for e.g. agency detection devices, theory of mind capacities, creationist biases, dualist biases, and a tendency to recall and spread minimally counterintuitive or MCI narratives] operating in ordinary human environments typically lead to some kind of belief in supernatural agency and perhaps other religious ideas. Special cultural scaffolding is unnecessary. Supernaturalism falls near a natural anchor point .... (Barrett 2010, 169)

Paul Bloom is even more explicit. He claims that diverse and, we might add, often incompatible forms of religious expression are cognitively natural, with the result that theism is not especially cognitively unique:

... there is no evidence that belief in a single God ... is unlearned ... Plantinga $(2000,197)$ asserts that 'awareness of God is natural, widespread, not easy to forget, ignore or destroy,' but these properties apply better to supernatural belief more generally, not to belief in God. (Bloom 2009, 127)

Now it might be thought, if religion is cognitively natural, that CSR would in reality soften worries about religious diversity and divine hiddenness. After all, if religion is part of our natural cognitive endowment, this evidences that God, if God exists, is personal and is doing something to make 
us religious: God is not just leaving things up to chance or to patterns of sociology, in other words. Such a response conflates two very different claims, however. One claim is that God would want people to be religious. Another claim is that God would want people to be religious in a particular way, namely a way that includes belief and trust in a high moral God in order to enjoy a divine-human relationship. Since theists typically affirm the second, more specific, claim and not just the first, one cannot alleviate the problem by saying that religion in general is cognitively natural or by saying that most people have some sort of religious belief.

Put another way, the problem of natural nonbelief is not a problem for religion in general or for supernatural religion in general, but for theism in particular. That many people naturally fail to believe in a theistic God plausibly sits much better with naturalism or deism than with theism. This is because it seems very surprising, given theism, but not given these other views, that the human mind would be naturally so insensitive to the truth about religion. (True, one could always claim that the religious mind is sensitive to the truth or is adequately truth-tracking, if placed in the right theistic environment. But then the problem becomes that it is too easy not to be in the right environment. ${ }^{16}$ )

\subsection{Two objections}

Some may object to my arguments by claiming that theism is more cognitively natural than its religious and secular rivals. ${ }^{17}$ But it is difficult to see how this claim (still controversial in CSR) would alleviate the problem. The problem, recall, is that the kind of mind we possess, along with the way in which our religious concepts have evolved, has contributed to much nonresistant nonbelief throughout history. Claiming that theism is more natural than its competitors won't change this: it will still be true that millions and millions of people have, in many cases naturally, failed to believe in a theistic or theistic-like God. If we add, with many exclusivists in the Abrahamic traditions, that people's salvation literally depends on their having rather specific religious beliefs, beliefs that go well beyond mere theism, then the problem gets even worse. In that case, it wouldn't matter if everyone were a theist. The problem will still emerge. People would still fail, if theism is true, to enjoy the right kind of divinehuman relationship. (But of course not everyone is a theist. Belief in God is not nearly that natural). 
Another objection concerns the problem of early nonbelief. Some might downplay the reality or significance of such nonbelief by claiming that God really was there "in primitive times ... revealing himself within the very limited capacities of humans to understand" (Stark 2007, 5). But there are problems with this strategy. For one, on Stark's own estimation, which is based on ethnographic data for roughly four hundred "pre-industrial" cultures, a huge portion of these cultures (from what I can tell, less than 50 percent) have apparently affirmed a High God, with far fewer affirming an active or moralistic High God that cares about the morality of human beings $(2007,60-61) .{ }^{18}$ If these numbers are anywhere near correct, they just restate the worry, for that is consistent with a lot of natural nonbelief.

As for the idea that God was present in the past, despite people's limitations, this can be hard to accept once we think of the kinds of limited supernatural agent concepts in question. As Darwin noted, many of the spirits affirmed in earlier cultures were hardly very powerful or very nice. Indeed, many similar spirits are still affirmed today. As Pascal Boyer notes, some spirits affirmed in certain regions of Africa want to eat people's children but can be outsmarted if parents refer to their children as ugly $(2001,7-8)$. Other spirits, affirmed in certain regions of Haiti, allegedly want to steal the corpses of the recently deceased, but thankfully, they are rather easily fooled out of it. Finally, even when it comes to higher deities, it is important to see that not all of these are interested in human salvation or well being. It can be difficult to imagine that the God of theism is all that present through ideas like these. It can be even more difficult to imagine that cultures that have been restricted to ideas like these experience the kind of valuable divine-human relationship that an unsurpassably loving God would arguably want for them during their lives. Since some present cultures, but especially earlier ones, were so restricted, ${ }^{19}$ Stark's suggestion is inadequate.

\subsection{The initial argument}

To formulate the problem, recall claim (1) from the outset of this article:

(1) Evolution gave rise to early humans who lacked a concept of God, the result of which has been much nonbelief in God.

I think (1) is true. But our target claim at this point is only that there was nonbelief among early humans, not that evolution played a causal role 
in giving rise to this nonbelief. We should thus bracket our knowledge of biological evolution at this stage of the argument by replacing (1) with $\mathrm{E}^{*}$.

E*: For a variety of biological, cognitive, and environmental reasons, early humans, including many anatomically and behaviorally modern humans, originally lacked a concept of God and were religiously restricted to concepts of limited, and sometimes mean, supernatural agents. As a result, many early humans, including many early anatomically and behaviorally modern humans, failed to believe in God or in anything like God. The nonbelief in question was both naturally occurring and nonresistant.

Just as there have been eons of natural suffering, $\mathrm{E}^{*}$ suggests that there was a notable period of naturally occurring nonbelief among early humans. To put the argument in a way that resembles Draper's argument from natural evil, we can say:

(P1) We know $\mathrm{E}^{*}$ to be true (or at least $\mathrm{E}^{*}$ is very plausible).

(P2) Naturalism has much more predictive power with respect to $\mathrm{E}^{*}$ than theism.

(P3) Naturalism starts out at least as plausible as theism (i.e., naturalism is at least as probable as theism independent of all evidence).

(C) So, other evidence held equal, theism is very probably false.

We have seen the evidence for P1. The testimony of scientists and religious scholars combined with our knowledge of how cultural evolution works supports P1. As for P2, given how we have defined naturalism and theism, P2 can also seem hard to resist. Given naturalism's commitment to indifference about whether early humans would be theists, and given that a perfect God would desire to enter into a divine-human relationship with early humans, naturalism makes $\mathrm{E}^{*}$ comparatively much more likely than theism. Again, God might have reasons that we can't imagine for permitting $\mathrm{E}^{*}$, as so-called skeptical theists will point out. ${ }^{20}$ But again, it is no less likely that God has reasons that we can't imagine for never permitting $E^{*}$. (Besides, that we know what to expect on naturalism seems to count in favor of naturalism.) Finally, as for P3, it is a 
widely held assumption that I am making throughout this paper that theism and naturalism start out roughly equally likely. To avoid disputes about intrinsic probabilities, however, we could state the argument in the form of a likelihood inequality.

$$
\operatorname{Pr}\left(\mathrm{E}^{*} \mid \text { naturalism }\right)>\operatorname{Pr}\left(\mathrm{E}^{*} \mid \text { theism }\right)
$$

Lastly, since other factors besides $\mathrm{E}^{*}$ might better support theism than naturalism, it is important to see that the argument here is:

$$
\operatorname{Pr}\left(\mathrm{E}^{*} \mid \text { naturalism }\right)>\operatorname{Pr}\left(\mathrm{E}^{*} \mid \text { theism }\right)
$$

as opposed to:

$$
\operatorname{Pr}\left(\text { Naturalism } \mid E^{*}\right)>\operatorname{Pr}\left(\text { Theism } \mid E^{*}\right) .{ }^{21}
$$

\section{What Darwinism Contributes to the Problem of Natural Nonbelief}

We have seen that belief in God is, cognitively speaking, much less natural than we would expect if theism were true, but not less natural than we would expect if naturalism were true. This fact, if it is a fact, does seem to favor naturalism over theism. But we can say more than this. In the same way that the problem of natural evil was intensified by our awareness of evolution, and specifically Darwinian evolution, something similar may be said here as well. Darwinism intensifies the problem of natural nonbelief. The reason for this is twofold. First, Darwinism is highly optional on theism: it is much more to be expected on naturalism than on theism. Second, Darwinism gives us reason to expect $\mathrm{E}^{*}$ and further helps to explain $\mathrm{E}^{*}$. If these two claims are correct, then the ratio of the predictive power of naturalism to the predictive power of theism with respect to $E^{*}$ will further increase.

So are these two claims correct? The answer seems to be yes. Beginning with the first claim, we have already seen reason for thinking that Darwinism starts out more likely on naturalism than on theism. This is because an omnipotent God would have many non-Darwinian ways to create minds, bodies, and souls and would not be limited to Darwinian or even physical constraints. For instance, God might infuse souls with religious knowledge, or God might hardwire a tendency to form belief in God in the brains of nonresistant persons, while finding ways of dissuading 
people from affirming the competitors to theism. (I am of course assuming here that God could orchestrate and oversee the process of creation to ensure that fairly specific ends would be obtained in the world. But this assumption should not be too controversial to the evolutionary theist. ${ }^{22}$ ) By contrast, if naturalism is true, then the options for developing life are much more constrained, especially in the relevant time frame. In the absence of Darwinian processes, life's development seems exceedingly unlikely.

Turning now to claim two, this, recall, says that Darwinism gives us reason to expect $E^{*}$ and indeed helps to explain $E^{*}$. This claim also seems true. To see why, it is helpful to consider the relationship between evolution and religion. According to those working within CSR, there are three basic ways of thinking about religion and natural selection. Religion might be an evolutionary byproduct stemming from mental architecture and capacities that evolved for nonreligious purposes (Barrett 2004); or religion might be adaptive, and so selected for directly (Norenzayan and Shariff 2008); or religion might start out as a byproduct of evolved capacities and later be co-opted for adaptive purposes (Powell and Clarke 2012). No matter which option one favors, the point is that serious religious diversity and early nonbelief in a theistic or theistic-like God is to be expected.

Beginning with the byproduct interpretation, there is no reason to expect that cognitive tools that were designed by natural selection for nonreligious purposes would, in turn, lead people to favor theism and disfavor alternatives to theism. In fact, since the outputs of our mental tools, like our agency detection devices, are likely to be highly nonspecific and highly sensitive to local factors in the environment, then the byproduct view gives us reason to expect serious religious diversity and early nonbelief in God. For instance, consider our hypersensitive agency detection device (HADD), which helps us to detect agents in our environments but which can easily misfire. With this mental tool in play, those in the forest might come to a belief in forest spirits, whereas those in more stormy regions might come to believe in angry sky deities. Nothing about HADD or other capacities discussed in CSR requires that one will come to believe in God. If anything, it seems like theistic concepts would later evolve from nontheistic concepts that were initially triggered by mental tools like HADD.

Turning to the evolutionary interpretation of religion, there is no reason to expect that theism would be adaptive and the religious rivals to theism maladaptive. Even in the absence of theism, after all, the belief that 
vengeful ancestor sprits, ghosts, or invisible witches are watching could arguably play the role of taming possible cheaters in a group and of motivating prosocial behavior (Piazza and Bering 2011; Norenzayan and Shariff 2007). Adding with the hybrid view, finally, that religion starts out a byproduct and is later co-opted for adaptive purposes will not make $\mathrm{E}^{*}$ any more or less likely, since there is nothing about this option that would have new bearing on $\mathrm{E}^{*}$. These claims support the conclusion that $\mathrm{E}^{*}$ is unsurprising, and even somewhat likely, on Darwinism - at least, again, if human-like creatures are to emerge. ${ }^{23}$ If that is correct, then even in the absence of a detailed scientific account of religion, there is a meaningful relationship between natural selection and $\mathrm{E}^{*}$. In other words, we have new Darwinian support for naturalism.

\subsection{Implications for religious epistemology and the fall}

I am not the only person to raise this last problem. Justin Barrett seems to appreciate the worry, albeit only briefly, when he says:

If . . God created humans so that they might enjoy a relationship with Him, why would God leave such important cognitive capacities to chance plus natural selection ... why do the documented conceptual biases only encourage belief in superhuman agents generally and not in one true, accurate god concept? ... why not hard-wire into our brains a fully formed belief in God? $(2008,97)$

These are good questions, though Barrett's own response is surprising. He states, in effect, that God did hardwire a fully formed belief in God into the minds of the first humans, adding that the "diversity of god concepts we see is a consequence of human error and not divine design" $(2008,97)$. Barrett adds that in the absence of certain moral flaws in the world, "perhaps children would inevitably form a perfect concept of God" (2008, 97).

These are strong claims, and I am not sure how seriously Barrett intends them. Aside from being poorly evidenced, they are problematic on various levels (and ignore some of the richer literary features of fall narratives). For one, they contradict Barrett's earlier claim that ancestor spirits are the first and most widespread of religious concepts. Second, the above remarks further make a prediction that few scientists will bet on: namely, that if we look long and hard enough, we may well uncover evidence that the earliest humans had full-blown theistic beliefs. Third, whatever scientists would be willing to bet on, animal suffering in the distant past already diminishes the explanatory power of the fall, histori- 
cally conceived. This should lower our confidence that the fall can explain nonbelief in the distant past. Fourth, it can seem historically and theologically implausible to think that religious concepts were reset in response to the moral failure of early humans, such that the social world gradually underwent the kind of cultural evolution that we would expect if naturalism were true: beginning, roughly, with ancestor spirits, animism, polytheism, henotheism and then eventually moving on to theism, at least in some regions. Fifth, there is no clear normative connection between the fall and its alleged doxastic consequences. Why should moral failure lead to serious religious diversity in the first place, and why should it disadvantage some cultures far more than others? Aren't most cultures, on standard theological views, supposed to be comparably fallen? Sixth, although science cannot strictly rule out that an early human pair fell, leading to radical changes in people's religious environments and/or the structure of human cognition, this causal connection can seem highly implausible, even if we suppose that theism is true. I am thus doubtful that appeals to the fall will resolve the problem of natural nonbelief.

Finally, these remarks, aside from challenging Barrett's claims, further cast doubt on a basic tenet of the most familiar expression of religious epistemology, according to which belief in God is natural, and according to which the failure to believe in God is, far from natural, wholly due to sin. For instance, Alvin Plantinga, drawing on the writings of Aquinas and Calvin, states: "Were it not for sin and its effects, God's presence and glory would be as obvious and uncontroversial to us all as the presence of other minds, physical objects, and the past. Like any cognitive process, however, the sensus divinitatis can malfunction; as a result of sin, it has indeed been damaged" (2000, 177). Plantinga, in understanding the sensus divinitatis in highly theistic terms, makes an apparently historical claim that we have reason to believe is not borne out, namely, that "human beings as originally created ... had extensive and intimate knowledge of God" $(2000,204)$. The present discussion makes it harder to affirm this widely held claim. ${ }^{24}$ This suggests that the significance of natural nonbelief extends beyond mere theism to much Abrahamic religion. ${ }^{25}$

\section{Nonbelief After 1859}

The problem we have considered is roughly this: why, if God exists, did it take so long for humans to develop theistic concepts, and why is the- 
istic belief not, in general, more cognitively natural than it is? I now want to turn to a related problem that runs as follows: why would God use evolution to design the living world when the discovery of evolution would predictably contribute to so much nonbelief in God? This last question is rarely asked, but in light of the serious impact of Darwinism on science and culture, it should be. Roger White nicely discusses some of this Darwinian impact on culture:

Prior to Darwin there was a quite compelling argument from design, a kind of inference to the best explanation. William Paley (2006) was right to think that the intricate machinery of the mammalian eye and other biological wonders cried out for explanation, and that the only compelling explanation available at the time was theism, or at least some kind of powerful intelligent agency. But Darwin (1998) changed that. In giving a better explanation (or at least the framework for such an explanation) Darwin undermined Paley's argument, thus removing this potential source of justification for theism. $(2010,584)$

White is no doubt correct about the biological design argument. ${ }^{26}$ But he adds a qualification that I think is mistaken. He states: "I think something like the explanation above is the only credible way that evolutionary biology could be thought to have epistemological relevance to theism" $(2010,584)$. This claim is mistaken, at least if the claims of evolutionary biology can include factors like evolutionary evil and evolution-based nonbelief. For as I shall now argue it is not true that the only way for these evolutionary factors to pose epistemic trouble for theism concerns the design argument.

\subsection{Experiential considerations}

First, there is the reality of irreligious experiences in nature, which are epistemically significant. Coming to see that our biological origins are compatible with theism's main epistemic competition in the Westnamely, metaphysical naturalism-can, whatever its inferential significance, lead some persons to directly and justifiably sense that we live in a naturalistic universe. As with Smith's experience of biological suffering and competition, cited earlier, the problem here is noninferential. One may just immediately come to sense that "God wouldn't do things this way." Or one might come to sense that "the world is a chancy and in many ways cold and impersonal place," and that "there is no ultimate reason for our existence." Experiences like these can and often do 
happen. And although many theists can and do accommodate evolution (Miller 1999), the claim here is only that many find the task of accommodation intellectually and experientially difficult. For instance, consider the following testimony from Louise Antony:

It seemed to me that if evolutionary theory was correct, then biological differences were a matter of degree: apes just gradually become people. But that seemed parlously at odds with a religious picture: that human beings, in virtue of possessing immaterial souls, were fundamentally different from everything else in nature. I decided that I should try not to believe in evolution. $(2007,45)$

In response to this passage, one might be tempted to object that it rests on two inferential mistakes: evolution does not establish that we lack souls, and theists can be materialists about human persons. But all of this misses the point. Even if no decent argument against theism can be constructed from the above passage, the best way of reading the passage is more personal: it reveals a fairly common, understandable, and powerful form of irreligious experience. Since a divine being would presumably care about this consequence, and since noninferential defeat is something that many theistic philosophers worry about, ${ }^{27}$ passages like those above are clearly significant. Finally, since irreligious experiences seem highly involuntary, the nonbelief they give rise to is a good candidate for being nonresistant.

In light of these remarks, claim two from the outset of the paper seems plausible:

(2) An acquaintance with evolution directly leads many to sense that the universe is indifferent to them, which often weakens or destroys their belief in God.

White's suggestion thus fails on account of (2), particularly if the nonbelief described in (2) is often epistemically justified. ${ }^{28}$

\subsection{Inferential considerations}

White's suggestion also fails to appreciate the many ways in which an awareness of evolution can do inferential epistemic damage. For instance, there is Draper's evolutionary argument from evil, and his argument that evolution starts out more likely on naturalism than on theism. Similarly, there is the ancient-earth thesis, which is often thought to be part of evolution. As some theists will acknowledge, that the earth (and 
universe) is old is required on naturalism but optional on theism (Moler 2010). Claims like these are epistemically significant. In fact, we know empirically that much less plausible evolutionary arguments than these, for instance arguments from Richard Dawkins, can have serious impact on people's belief in God (Shariff, et al. 2008). Some of these claims certainly have bearing on the force of biological design arguments. But their epistemic significance is not exhausted by their impact on such arguments. They also give rise to nonbelief, which is a form of higher-order evidence and which can be relevant to hiddenness arguments, as we shall soon see. Thus claim three:

(3) An acquaintance with evolution generates certain atheological arguments and further tends to undermine biological design arguments, which for some weakens or destroys their belief in God.

In short: even in the absence of (1), facts (2) and (3), when combined, make the claim that a divine being would opt for an evolutionary means of creation more surprising than this claim would otherwise be. This is particularly so if we are concerned about divine hiddenness, which we will soon consider in more detail. If we add Draper's argument from natural evil and my claims about natural nonbelief to the mix, then the combined force of these various arguments might be thought to offer a particularly important challenge to theism. The challenge here, to clarify, need not be that theistic belief is irrational or that it requires arguments (or answers to every objection that arises) for its rationality. We can easily make rationality very easy or very hard, if we want to (Marsh forthcoming). The challenge is, rather, that theism is notably less likely to be true than we thought, given the present claims, which is surely significant, at least for those who care about the evidence and who have doubts about whether theism is true. ${ }^{29}$

\section{Implications for Divine Hiddenness}

In this final section I will draw some implications for the evidential argument from divine hiddenness, which, recall, says that nonresistant nonbelief in God provides evidence against theism. ${ }^{30}$ Now we have already considered some implications for divine hiddenness. As we saw earlier, my arguments make it harder to reject the reality of nonresistant nonbelief. My claims also uncover a more severe form of nonbelief. For 
given (1), it wasn't merely difficult, but impossible, for many early humans to have a divine-human relationship. This is because if the relevant individuals and groups lacked a theistic concept, they couldn't have believed. Such a claim is significant, for although some will debate whether religious belief is really required for religious faith, or for a corresponding divine-human relationship (Audi 2008; Schellenberg 2007; Schellenberg 1993), few will deny that having a relationship with God requires at least a concept of God.

True, some will insist that we already have plenty of evidence for nonresistant nonbelief. But my claims also pose an explanatory challenge for theism and undermine traditional solutions to divine hiddenness. Beginning with the explanatory challenge, the shiftiness of nonbelief over evolutionary time is much easier to explain on naturalism than on theism. After all, given naturalism, we can simply point to the kinds of Darwinian and cognitive factors that make (1), (2), and (3) plausible. Naturalism thus doesn't have an especially hard time explaining historically uneven patterns of nonbelief. What about theism? Theism has a much harder time here. (Of course, if theism is conjoined with evolutionary and cognitive science, then scientifically minded theists could invoke the same natural explanations for nonbelief held by the naturalist. But part of the lesson here, recall, is that God has reasons not to opt for modes of creation that give rise to facts like (1), (2), and (3), that (1), (2), and (3) are surprising on theism.)

Finally, whatever we make of naturalism's comparative advantage in explaining (1), (2), and (3), these facts tend to undermine traditional theistic solutions to divine hiddenness. Again, the process and discovery of evolution have apparently had a highly uneven impact on belief in God throughout history. This matters, since shifty patterns of nonbelief in the present already pose a problem for theism (Marsh 2008; Maitzen 2006). ${ }^{31}$ If we factor in the temporal unevenness of nonbelief and its connection to evolutionary and cognitive factors, then traditional explanations of divine hiddenness become even less plausible.

For instance, consider John Hick's well-known Irenaean theodicy, according to which divine hiddenness and serious religious uncertainty are good for us. The basic idea here is straightforward enough: only in environments of genuine religious ambiguity, where a sufficient epistemic distance from God exists, can genuine freedom and moral development take place for human beings. If that is right, then we shouldn't be too sur- 
prised if nature is both "capable of being seen as a purely natural phenomenon and of being seen as God's creation" (1981, 43). Since, as Hick realizes, the religious ambiguity he speaks of is encouraged when we come to see ourselves and our world in evolutionary terms, it might be thought that we have a good theistic explanation, not just of nonresistant nonbelief in general, but of evolution-based nonbelief in particular.

In response: whatever the merit of the moral development or soulmaking reply in response to more traditional hiddenness arguments, it seems powerless against my claims. For one thing, the discovery of evolution is a relatively recent one. Prior to 150 years ago, people generally believed in some form of special creation, in part because there wasn't a credible naturalistic answer to the question of how complex life developed. And yet these individuals, assuming the truth of theism, were presumably capable of properly relating to God. Our knowledge of Darwinism thus isn't required for soul building or for human autonomy. Second, given $E^{*}$, early humans were at a rather radical epistemic distance from God. Are we to seriously suppose that people at different times required vastly different degrees of epistemic distance from the divine? Are we to suppose that contemporary individuals, for instance, require much more epistemic distance from the divine than, say, medieval Europeans, for whom God's existence was largely taken for granted, but much less epistemic distance from the divine than early humans, who hadn't so much as a concept of God? Since the answer to these questions is surely no, Hick's theodicy fails to touch the historical unevenness of nonbelief described in (1), (2), and (3).

Something similar can be said of Michael Murray's related anticoercion response to divine hiddenness (2002), which takes the form of a defense as opposed to a theodicy. ${ }^{32}$ According to this defense, were God known with clarity to exist, and were God taken to be a personal judge of human beings, then this could provide too much incentive to obey divine commands and could detract from our ability to disobey. (Just as we cannot easily resist a thief with a gun, given what is as stake, so too we couldn't freely resist God, if divine truths were too clear.) Since God is not coercive, the implication is that we shouldn't be surprised to find that God's existence and nature is less than clear.

In response: again, such claims, whatever truth they contain, fail to explain the relevant facts. We have no reason to expect that early nonbe- 
lievers were any more prone to divine coercion than later humans, just as we have no reason to suppose people in the centuries preceding Darwin were less sensitive to divine coercion than those living after Darwin. As in the case of Hick's theodicy, Murray's defense is not sensitive to how much the hiddenness of God has fluctuated over evolutionary time.

Other examples could be cited as well..$^{33}$ The result is that some of the best-known solutions to the traditional problem of divine hiddenness, whatever insights they may have, go little or no distance when it comes to explaining evolution-based nonbelief and its shifty character throughout history. Combining these various strategies won't help either, unless they can plausibly explain the patterns described in (1), (2), and (3).

\section{Conclusion}

To sum up: this paper explored the problem of why God would use natural selection to design the living world when the process and discovery of Darwinism would contribute to so much nonbelief in God. This problem can be seen as an interesting puzzle for theists to explore. But as we saw, it also has evidential significance for the debate between naturalism and theism, for Draper's evolutionary argument from evil, for Plantinga's religious epistemology, for divine hiddenness, and for the discussion about whether the relationship between evolution, cognitive science, and theism is problem-free.

This last issue is important, for although there is no shortage of evolutionary critics of religion who wrongly suppose that science somehow straightforwardly disproves theism, there is also no shortage of overly cheery theistic assessments of evolution. For instance, Martin Nowak's claim that evolution should be "as little problem for religion as [the concept of] gravity" (2007) seems highly questionable in light of the above arguments. ${ }^{34}$ Finally, my arguments, although they lend support to naturalism, do not show that theism is false or implausible or irrational, all things considered - nor have I suggested otherwise. But my claims are significant for those who, like me, want to take on the difficult task of weighing the evidence for naturalism and theism, and who want to assess the relationship between religion and science. ${ }^{35}$

Jason Marsh

St. Olaf College 


\section{Notes}

1. Darwin's own views about religion are complex. It is sometimes said that Darwin became an agnostic later in life and that his agnosticism was largely attributable to his daughter's death and to the problem of evil. I am no historian of Darwin, but some passages give me the sense that evolution also played a role in giving rise to his religious doubts, robbing him of his former sense of teleology, even while keeping his sense of nature's grandeur intact.

2. It is not entirely clear to me whether Sober thinks there are any serious evidential conflicts between evolution and theism (as opposed to, say, evolution and something more specific like young earth creationism). He certainly seems right that the theory of evolution and theism are logically compatible, and that talk of unguided mutations in science does not vindicate naturalism (2011). He also seems right to say, if we're talking about a bare designer, that we will not know much about the designer's aims or goals, something that creates trouble for the ID movement. But Sober also occasionally seems to admit that evil, or bad design in nature, could pose an evidential problem for theism, which is a much more specific hypothesis than the bare hypothesis of intelligent design. He states: "Maybe the existence of so much evil is evidence against such a [theistic] being . . . In an earlier publication (Sober 2004b), I took the view that the organismic design argument and the argument from evil are precisely on a par in that both require assumptions that we are not entitled to make. Now I am not so sure. Perhaps the design argument requires more knowledge of the designer's goals than the argument from evil does" (2008, 166-67).

3. Despite something White (2007) calls the preference problem for design arguments, he seems to think that cosmic fine tuning and life's origin, which are of course distinct from life's evolutionary development, are at least somewhat more likely on a design hypothesis than on other hypotheses, including the chance hypothesis.

4. My focus on theism and naturalism in this paper is explained by my sense that these are two of the most plausible world pictures on offer, at least at the present time, and because they are in conflict with one another. I realize that theism is much more than a world picture or hypothesis for theists and that some would resist testing it at all.

5. I should clarify that I think that the concept of an "unsurpassably loving God" is incompatible with certain Calvinist ideas of the divine, according to which God's love looks pretty selective. I will take for granted that God's love, being perfect, extends radically toward all individual persons and even creatures in history.

6. The claim here is not that nature literally has a mental state that we might refer to as indifference. The claim is rather that there is nothing at the core of reality, if naturalism is true, to display care for human beings.

7. I realize that there are genuine debates about the extent to which natural selection, as opposed to other mechanisms, is responsible for evolutionary change and that we might learn more about this. But if Darwinism, or more accurately neo-Darwinism, is nearly as well evidenced as most scientists seem to suspect, then those who reject it already face enough epistemic trouble as is. That the theist who rejects a Darwinian, or even evolutionary, outlook can avoid many (though not all) of the problems developed here should thus be of minimal consolation.

8. According to skeptical theists, inferences like the following are highly questionable: we cannot see a good moral reason for X, so there probably isn't one (if there were such a reason for $\mathrm{X}$, after all, we'd likely know what it is). I agree that such noseeum inferences are often fallacious, but I also think that we reasonably make them in some contexts, 
including some moral and scientific contexts. In any case, it is worth noting that comparative arguments like Draper's, and those I raise later on, do not clearly succumb to skeptical theist worries. In fact, some well-known skeptical theists seem to admit this. Bergman and Howard-Snyder, for instance, state that Draper-style arguments "seem to refrain from depending on noseeum assumptions" $(2004,16)$. These thinkers add that "the focus here is not on our inability to see a justifying reason but on our supposed ability to see that an atheistic explanation is superior to a theistic one" $(2004,24)$. A similar point is made by Elliott Sober when he tells us that "the evidential argument [from evil] is consistent with our having considerable uncertainty about what God's motives would be in allowing horrible evils to exist. The question is whether E's improbability increases if there is no God" $(2008,167)$.

9. Draper's actual premise is this: "Naturalism is more plausible than theism (i.e., naturalism is more probable than theism independent of all evidence)." Draper's arguments for this stronger premise, which concern simplicity and scope, are interesting, but I will set them aside. As Draper notes elsewhere (2007b), his strong premise is not required to get his conclusion. My weaker premise will also get his conclusion. Anyhow, I confess that it can be difficult to have confidence about the a priori factors determining the prior probability of a hypothesis. Figuring out the a posteriori factors is hard enough.

10. I am assuming that the existence of biological beings, including intelligent biological beings, isn't terribly unlikely on either naturalism or theism. This assumption may of course be false, which could pose a problem for everyone. For instance, if naturalism is true, then the existence of any life might be highly unlikely (perhaps it is hard to get the right number of planets or universes). But something similar goes for theism. After all, a perfect God, for all we know, might not create at all, or might not be interested in the kind of life we in fact observe. Perhaps this God would only want angels or immaterial souls who, lacking bodies, are more like God than us. Certainly the fact that we are physical and biological beings seems more likely on naturalism than on theism, even if other facts about us (e.g., that we are good at abstract science and math) are more likely on theism. I thus don't think that the theist should try to get out of the quandary by pointing out that life's existence is relatively improbable on naturalism.

11. Many of which seem rather far-fetched, even for defenses. Here, some claim, in a neo-Cartesian fashion, that such animals, for all anyone knows, were not conscious in a morally significant way (Murray and Ross 2006). Others have offered an antiregularity defense (Van Inwagen 2006), according to which a world without the kind of suffering reported by E may well have to be massively irregular - which is alleged to be at least as undesirable as a world marked by animal suffering. Still others raise the suggestion that animals might be compensated with post-mortem goods in the hereafter (Bergman and Howard-Snyder 2004, 24-25). These are not the most controversial moves, however. Some, resting on a rather sharp normative distinction between doing and allowing, appeal to the fall of angels, claiming that God might allow "Satan and his minions" to "play a role in the evolution of life, steering it in the direction of predation, waste and pain" (Plantinga 2011, 59). Finally, some claim that human sin can still be causally responsible for animal suffering if we accept some form of backward causation (Dembski 2010).

12. I am not worried about nonbelief in highly limited supernatural agents. As long as God is imagined to be exceedingly powerful, loving, and intelligent, my arguments carry some force. My arguments are especially designed for theism, however, where they carry the most force.

13. In some contexts Moser's strategy seems to be one of attributing all nonbelief to sin (Moser 2002). This move is unsurprising, since he also grants that "God as perfectly 
loving toward all people would seek to communicate with people if this was in their best interest, and this God would offer in that case some kind of evidence of God's reality" $(2008,37)$. In another context Moser claims that the problem of divine hiddenness arises from a presumptuous spirit, one that overlooks that Abrahamic religion is filled with narratives about divine hiding (2004). Such a response, however, misconstrues the argument and the technical meaning of divine hiddenness - which is really about nonresistant forms of nonbelief. As Schellenberg notes in his reply to Moser: "I agree with Paul Moser that there is no reason to expect a God of the sort whose existence is at issue here to 'be obvious to all normal humans,' or to encourage 'mere intellectual assent' to theistic claims ... I also agree that there is something deeply wrong with the 'kind of cognitive idolatry where we demand a certain sort of knowledge or evidence of God inappropriate to a filial relationship with God' . . . But I do not agree that significant arguments from divine hiddenness against theism are to be associated with such expectations and demands" (2004, 54).

14. Elsewhere Darwin states, "there is ample evidence ... that numerous races have existed, and still exist, who have no idea of one or more gods." But he adds, "The question is of course wholly distinct from that higher one, whether there exists a Creator and Ruler of the universe; and this has been answered in the affirmative by some of the highest intellects that have ever existed" $(2004,116)$. Darwin's qualification is correct. But of course the data in question might nonetheless have relevance to the truth of theism.

15. The point here, to clarify, is not that we know exactly how long it took for belief in God to emerge, or even to claim that we know all that much about early religion. The point is, rather, that scientific testimony, combined with our knowledge of how cultural evolution works, suggests that there was a time in the history of religion without theism.

16. To cite an analogy, if the earliest humans and some later humans naturally found themselves in environments in which they couldn't breathe, one might question whether their breathing apparatus was properly designed for breathing. Surely, however, one would wonder about their environments.

17. For an argument that theism is more cognitively natural than both metaphysical naturalism and highly abstract forms of religion like Schellenberg's Ultimism, see my forthcoming "Assessing the Third Way."

18. Thanks to Josh Thurow for leading me to this source and for raising the objections that he did.

19. I am thus not denying that present day cultures who affirm limited spirits sometimes also affirm a High Moral God.

20. For my earlier discussion of skeptical theism, see note eight.

21. The likelihood of a hypothesis, in other words, is the probability that a hypothesis confers on an observation and not the probability that an observation confers on a hypothesis. To be sure, there are complexities and disputes that arise even over views like 'likelihoodism', which are much more modest than views like Bayesianism (Sober 2008), but I will leave these complexities aside. Philosophers have many disagreements about probability and about how to best express arguments like those we are discussing.

22. As Plantinga states: "God could have preserved populations from perils of various sorts, and so on; in this way, by orchestrating the course of evolution, he could have ensured that there come to be creatures of the kind he intends" $(2011,4)$. Plantinga's claim provides a plausible response to those who, like Stephen J. Gould and Michael Ruse, seem to think that humans might not have evolved at all, even if theism is true, given the highly contingent nature of evolution. But it also raises the likelihood that God could orchestrate 
the course of evolution to ensure that there come to be the kinds of religious minds and religious outlooks that God intends. Finally, as for those who think that God would basically never intervene in nature, I have yet to see convincing arguments for this conclusion.

23. See note 10 .

24. Stephen Maitzen (2006) advances a similar challenge to a highly theistic conception of the sensus divinitatis by focusing on current patterns of nonbelief around the world. I think Maitzen's case can be improved by factoring in temporal and specifically, evolutionary, patterns of nonbelief. I will discuss these patterns more in due course.

25. This is important since, as Richard Otte (2012) notes, following Carnap, some evidence can disconfirm the core of a set of beliefs without disconfirming the larger set of beliefs. For instance, the reality of evil might be thought to disconfirm theism without thereby disconfirming Christian theism, since the latter entails that there will be evil. Unfortunately, for many Abrahamic theists, however, the same cannot be said about natural nonbelief. In fact, many Christian theists think that scriptures, such as the first chapter of Romans, require that all nonbelief is culpable, foolish, and never natural. Natural nonbelief at the very least poses a problem for believers who interpret scripture this way.

26. Some go further than White. For instance, Peter Van Inwagen claims that "the very existence of Darwin's account - whether or not it is true-renders all versions of the design argument considerably less cogent than they would have been if no one had thought of it" $(2003,348)$.

27. Interestingly, Alvin Plantinga grants that noninferential defeaters are the most powerful threat in the context of the problem of evil (2000, 484).

28. Perhaps White does not intend to deny (2), and perhaps he would grant my claims about the significance of noninferential defeat. Still, the mistake I attribute to him is sufficiently common as to be worth correcting.

29. Draper makes a similar point in his response to Plantinga (2007b).

30. Again, nonresistant nonbelief is supposed to offer evidence against God's existence since (a) such nonbelief seems to preempt persons from enjoying a valuable divine-human relationship in this life and since (b) God, being perfectly loving, wants this relationship for people in this life and arguably just as soon as it is possible. There are also nonevidentialist or deductive versions of the hiddenness argument (Schellenberg 2007), versions that, if successful, would disprove theism all by themselves. But I confess that I find these versions of the argument too strong.

31. One might wonder whether my Molinist solution to the geographic problem of divine hiddenness has bearing on my present arguments. That response says, roughly, that Maitzen's worries about uneven patterns of nonbelief in the present overlooks that God could use divine middle knowledge (roughly the knowledge of what people would do in any feasible circumstance) and divine hiding to help to secure the eventual salvation of everyone, especially those who were most hidden from in the present. Now I think that the very existence of such a response, whether or not it is true, weakens the force of problems raised by Maitzen and myself. This is because such explanations, whether or not they are true, evidence that there might be a grand and morally satisfying reason for divine hiding that we are missing. That said, I do not think that Molinist accounts of divine hiddenness fully undermine the force of my present arguments. In fact, my present arguments seem to pose a problem for Molinist solutions to divine hiddenness. After all, Molinism does not predict that various nontheistic religious outlooks, and not just theistic ones, would be cognitively natural. Relatedly, God could presumably isolate various individuals for their 
eventual benefit, if theism were true, without giving them over to a religion of cruel spirits. In short, naturalism might still be said to better explain the relevant data than theism.

32. Whereas theodicies have traditionally sought to give us God's actual reasons for causing or permitting evil and/or divine hiddenness, defenses are more modest: they are supposed to give us reasons that, for all we know, would justify God's actions.

33. For instance, according to Dougherty and Poston (2007), once we adopt a more dynamic view of belief, one that permits various degrees of belief and periods of serious doubt, we can largely overcome Schellenberg's classic problem of divine hiddenness. Whether or not that is so, the relevant claims do nothing to challenge early (full-out) nonbelief.

34. And there remains some conflict even if evolution also leads to certain forms of cooperation and altruism. It is not just Nowak who upholds the no-conflict view, however. According to Peter Van Inwagen, the "truth or falsity of Darwinism has no more to do with truth or falsity of theism than does, say, the hypothesis of continental drift" $(2003,352)$. Perhaps Van Inwagen simply means that the theory of evolution and theism are not in logical tension. If so, I agree. But many theistic scientists, theologians, and some philosophers seem to mean something much stronger than this. They seem to mean that, perhaps with the exception of natural evil, there are no serious evidential tensions between evolution and religion.

35. Thanks to Tim Mawson, Klaas Kraay, J. L. Schellenberg, Richard Swinburne, Paul Draper, Bill Harper, Gillian Barker, Helen De Cruz, Michael Murray, Robert Audi, Josh Thurow, Pascal Boyer, Stephen Stitch, Jon Marsh, John Thorp, Justin Barrett, Kenny Boyce, and James Beebe for helpful comments and discussion. Thanks also to my audience at the conference 150 Years After The Origin of Species, held at the University of Toronto, and to audiences at Oxford, Duke, Western Ontario, and British Columbia, where earlier incarnations of this article were presented. Thanks most of all to the Cognition, Religion, and Theology (CRT) project at the University of Oxford, supported by the Templeton Foundation, for funding this research. The ideas presented here are mine and should not be assumed to reflect the views of the Templeton Foundation or any other institution with which I am affiliated.

\section{REFERENCES}

Antony, Louise 2007. "For the Love of Reason," in L. Antony, ed., Philosophers Without Gods: Meditations on Atheism and the Secular Life, Oxford: Oxford University Press, 41-58.

Audi, Robert 2008. "Belief, Faith, and Acceptance," International Journal for Philosophy of Religion 63: 87-102.

Barrett, Justin 2004. Why Would Anyone Believe in God? Lanham, MD: Altamira Press. . 2007. Religious Compass 1 (6), 768-86.

2009. "Cognitive Science, Religion and Theology," in M. Murray and J. Schloss, eds., The Believing Primate: Scientific, Philosophical, Theological Reflections on the Origin of Religion, Oxford University Press, 76-99.

_. 2010. "The Relative Unnaturalness of Atheism: On Why Geertz and Markússon Are Both Right and Wrong," Religion 40 (3), 169-72.

Bergmann, Michael and Daniel Howard-Snyder 2004. "Evil Does not Make Atheism More Reasonable than Theism" in M. Peterson and R. Van Arrogan, eds., Contemporary Debates in Philosophy of Religion, Oxford: Blackwell, 13-24. 
Bloom, Paul 2009. "Religious Belief as an Evolutionary Accident," in M. Murray and J. Schloss, eds., The Believing Primate: Scientific, Philosophical, Theological Reflections on the Origin of Religion," Oxford: Oxford University Press, 118-27.

Boyer, Pascal 2001. Religion Explained: The Evolutionary Origins of Religious Thought, New York: Basic Books.

Darwin, Charles 1856. "Letter to Hooker 13 July," http://www.darwinproject.ac.uk/entry1924

2004. Descent of Man, Penguin Group.

Dembksi, William 2009. The End of Christianity, Nashville, TN: B\&H Publishing Group.

Dennett, Daniel and Alvin Plantinga 2011. Science and Religion: Are They Compatible? Oxford: Oxford University Press.

Dougherty, Trent and Ted Poston 2007. "Divine Hiddenness and the Nature of Belief," Religious Studies 43: 183-98.

Draper, Paul. 2007a. "Natural Selection and the Problem of Evil," in God or Blind Nature? Philosophers Debate the Evidence, http://www.infidels.org/library/modern/paul_ draper/evil.html.

- 2007b. "On the Plausibility of Naturalism and the Seriousness of the Argument from Evil," God or Blind Nature? Philosophers Debate the Evidence, http://www.infidels.org/library/modern/paul_draper/serious.html.

Haught, John 2000. God After Darwin: A Theology of Evolution, Boulder, CO: Westview Press.

Hick, John 1981. “An Irenaean Theodicy,” in S. Davis, Encountering Evil: Live Options in Theodicy, Atlanta: John Knox Press.

Maitzen, Stephen 2006. "Divine Hiddenness and the Demographics of Theism," Religious Studies 42: 177-191.

Marsh, Jason 2008. "Do the Demographics of Theistic Belief Disconfirm Theism? A Reply to Maitzen," Religious Studies 44: 465-71.

- Forthcoming. "Conscientious Refusals and Reason-Giving," Bioethics.

. Forthcoming. "Assessing the Third Way," in R. Trigg and J. Barrett, eds., The Roots of Religion, Ashgate.

Miller, Kenneth 1999. Finding Darwin's God: A Scientist's Search for Common Ground Between God and Evolution, New York: Cliff Street Books.

Moler, Dan 2010. "A Simple Argument Against Design,” Religious Studies 00: 1-8.

Moser, Paul 2002. "Cognitive Idolatry and Divine Hiding” in D. Howard-Snyder and P. Moser, eds., Divine Hiddenness: New Essays, Cambridge University Press, 120-48.

—. 2004. "Divine Hiddenness Does Not Justify Atheism," in M. Peterson and R. VanArragon, eds., Contemporary Debates in Philosophy of Religion, Oxford: Blackwell Press, 42-53.

. 2008. The Elusive God: Reorienting Religious Epistemology, Cambridge: Cambridge University Press.

Murray, Michael 2002. "Deus Absconditus," in D. Howard-Snyder and P. Moser, eds., Divine Hiddenness: New Essays, Cambridge: Cambridge University Press, 62-82.

Murray, Michael and Glenn Ross 2006. "Neo-Cartesianism and the Problem of Animal Suffering," Faith and Philosophy 23(2): 169-90.

Nowak, Martin 2007. Cited in "Can Science, Religion Coexist Peacefully?" http://www.nd.edu/ afreddos/courses/43150/noowak.htm

Otte, Richard 2012. "Comparative Confirmation and the Problem of Evil," in J. Chandler and V. Harrison, eds., Probability in the Philosophy of Religion, Oxford: Oxford University Press, $127-43$. 
Piazza, Jared and Jesse Bering 2011. "Princess Alice Is Watching You: Children's Belief in an Invisible Person Inhibits Cheating," Journal of Experimental Child Psychology 109: 311-20.

Plantinga, Alvin 2000. Warranted Christian Belief. Oxford: Oxford University Press. . 2007. "Objections to Draper's Argument from Evil," God or Blind Nature? Philosophers Debate the Evidence. http://www.infidels.org/library/modern/alvin plantinga/against-evil.html

. 2011. Where the Conflict Really Lies: Science, Religion, and Naturalism. Oxford: Oxford University Press.

Powell, Russell and Steve Clarke 2012. "Religion as an Evolutionary Byproduct: A Critique of the Standard Model," British Journal for Philosophy of Science 63: 457-86.

Norenzayan, Ara and Azim Shariff 2007. "God is Watching You: Supernatural Agent Concepts Increase Prosocial Behavior in an Anonymous Economic Game," Psychological Science 18: 803-809.

- 2008. "The Origin and Evolution of Religious Prosociality," Science 322: 58-62.

Schellenberg, J. 1993. Divine Hiddenness and Human Reason, Ithaca, NY: Cornell University Press.

. 2004. "Reply to Moser," in M. Peterson and R. VanArragon, eds., Contemporary Debates in Philosophy of Religion, Oxford: Blackwell Press, 54-58.

- 2007. The Wisdom to Doubt: A Justification of Religious Skepticism. Ithaca, NY: Cornell University Press.

Shariff, Azam, Adam Cohen and Ara Norenzayan 2008. "The Devil's Advocate: Secular Arguments Diminish Both Implicit and Explicit Religious Belief," Journal of Cognition and Culture 8: 417-23.

Smith, Quentin 1991. "An Atheological Argument from Evil Natural Laws," International Journal for the Philosophy of Religion 29:159-74.

Sober, Elliott 2008. Evidence and Evolution: The Logic Behind the Science, New York: Cambridge University Press.

2011. "Evolution Without Naturalism," in J. Kvanvig, ed., Oxford Studies in Philosophy of Religion 3, 187-221. Oxford: Oxford University Press.

Stark, Rodney 2007. Discovering God: A New Look at the Origins of the Great Religions, Harper Collins.

Van Inwagen, Peter 2003. "The Compatibility of Darwinism and Design," in N. Manson, ed., God and Design: The Teleological Argument and Modern Science, Routledge, 348-63.

. 2006. The Problem of Evil, Oxford: Oxford University Press.

White, Roger 2007. "Does Origins of Life Research Rest on a Mistake?" Noûs 41 (3): 453-77.

- 2010. "You Just Believe That Because . . .," Philosophical Perspectives 24: 573-615. 